\title{
Climate change and groundwater resources availability in the Great Limpopo National Park (Mozambique): the current state of knowledge
}

\author{
S. Vitale ${ }^{1} \cdot$ G. Sappa ${ }^{2}$ (D) F. Andrei ${ }^{2} \cdot$ M. Barbieri $^{1}$
}

Received: 29 September 2021 / Revised: 19 October 2021 / Accepted: 19 October 2021 / Published online: 27 October 2021

(c) The Author(s) 2021

\begin{abstract}
This work outlines a comprehensive study of groundwater resources supply in Mozambique's Great Limpopo National Park buffer zone in Southern Africa. To protect biological diversity and the water resources supply of dispersed communities of the buffer zone is a crucial problem to fix people in the region and, in the meantime, to boost the development of the Limpopo National Park. This work shows the current state of knowledge about this topic and try to point out some suggestions on technical solutions. Some previous studies concluded that two different main factors make a complex water supply in this area: (i) the rainwater distribution, it is hard to transform the rainwater into groundwater resources available for exploitation, and (ii) the common groundwater resources, rich in elements such as Boron (B), Mercury (Hg), Uranium (U), Zinc (Zn) and Lead $(\mathrm{Pb})$. The occurrence of these elements is linked to the presence of groundwater with long residence times, unsafe for people's health. The methodological approach adopted has been to assess the potential infiltration, applying the inverse hydrogeological budget technique, starting from the main outcropping geological units, in the study area. Due to the lack of meteorological data referred to Limpopo National Park, the gauge stations located in the Kruger National Park during the last 64 years have been, on the whole, considered. The target of the study has been to assess the trend of meteorological data and understand how precipitations could affect groundwater recharge and their availability. Without a strategy of biodiversity conservation and sustainable water resources management, they cannot be reached and guaranteed healthy conditions for local dispersed communities. A hydrogeoethical responsible approach is essential to protect biological diversity and hydrosocial cycle framework with integrative ecosystem services and nature-based solutions.
\end{abstract}

Keywords Inverse hydrogeological budget $\cdot$ Groundwater recharge $\cdot$ Biodiversity conservation $\cdot$ Climate change $\cdot$ Limpopo National Park · Mozambique

\section{Introduction}

The Convention on Biological Diversity (CBD) addresses the following formal definition of biodiversity: "the variability among living organisms from all sources including, among others, terrestrial, marine and other aquatic ecosystems and the ecological complexes of which they are part; this includes diversity within species, between species and of ecosystems" (United Nations 1992). This work focuses on the Limpopo National Park, one of the jewels in the crown

\section{G. Sappa}

giuseppe.sappa@uniroma1.it

1 Department of Earth Sciences, Sapienza University, Rome, Italy

2 Department of Civil Building and Environmental Engineering, Sapienza University, Rome, Italy of Mozambique's protected areas and its buffer zone. From a biodiversity perspective, the Limpopo National Park has various and unique genes, species and ecosystems. Furthermore, numerous updated studies(MacDonald et al. 2009; Vitale et al. 2017b; Sappa et al. 2018; Barbieri et al. 2019; Andrei et al. 2021) refer to the strong connection between groundwater management and biodiversity conservation. Therefore, integrative sustainable water sources management, including the groundwater component, is critical to support biodiversity and local communities, and it calls for an integrative view of ecosystem services. On a broader approach, this outlook is of great value for sustainable water resources management in shared a common ground, i.e., geoethics and hydrosocial cycle. Moreover, to assure the regular creation of integrative ecosystem services shall be based on human well-being, the satisfaction of communities needs and protection of natural systems. Currently, geoethics 
is committed to the reflection on the values which underpin appropriate behaviours and practices wherever human activities interact with the Earth systems (Peppoloni and Di Capua 2017). More recently, emerged the concept of hydrogeoethics focussed on ethical research and best practices related to responsible groundwater science and engineering management and interrelated dimensions such as environmental law, social sciences, cultural and traditional values (Abrunhosa et al. 2021). Carvalho and Chaminé (2021) also stated that this approach underlines personal scientific integrity and a comprehensive understanding of the problem to solve with an ethical approach. Additionaly, Linton and Budds (2014) point out the concept of the hydrosocial cycle as a socionatural process by which water and society are intrinsically overlapped over space and time to achieve a suitable for successfully sustainable water resources management.

On the other hand, much of the world biological diversity exists outside a formal protected and reserved areas network in the Mozambican region. Several biological diversity examples often result in a land that is managed for some form of agricultural production and the maintenance of rural livelihoods. Therefore, effective biodiversity conservation will require innovative ways to merge the needs of farmers and rural communities with the need to conserve globally significant biodiversity inside a healthy framework. Unfortunately, many Southern African Development Community areas are data-poor and poorly accessible (Barbieri et al. 2019), referring to meteorological and groundwater information. Therefore, it is pretty challenging to support managing groundwater to protect biological diversity crops and guarantee water supply for local communities. On the contrary, in South Africa, the government has made significant progress in re-shaping water governance since the early 1990s. As a result, the role of management in water governance and water politics has been emphasized to a large degree (Meissner and Ramasar 2015). Because of this, an essential first phase in developing conservation of biodiversity requires a reliable groundwater characterization and protection, especially where groundwater is fundamental for nature and human life, as it happens in Mozambique Limpopo National Park area and its buffer zone (FAO 2004).

\section{Study site}

The Limpopo National Park spreads on a surface of about $11.433 \mathrm{~km}^{2}$ in the Mozambican part of Limpopo River Basin, situated in the East of Southern Africa, between about $20^{\circ}-26^{\circ} \mathrm{S}$ and $25^{\circ}-35^{\circ}$ E. The Mozambique portion of the Limpopo Basin consists of gently undulating terrain, between ranges of hills and mountains, with numerous small tributary streams. The rich biodiversity of the Limpopo Basin can be attributed to its biogeographical location and its variety of topographical features. The lack of management of groundwater resources is evident in local community water supplies (Van der Zaag et al. 2010; Barbieri et al. 2019). Consequently, there is an inadequate water resources information system, which also affects people healthiness. Women and children spend their time collecting water. The exact location of the Limpopo National Park (LNP), bordering the Kruger Park, which is at the west of Gaza Province, near the South Africa border and the South of Zimbabwe border (Fig. 1).

The Limpopo National Park area in Mozambique is surrounded by its buffer zone, which is, according to UNESCO definition, "an area that should ensure an additional level of protection to areas recognized as a World Heritage sites", with an emphasis on the importance of these areas in the proper management of protected areas. Unfortunately, the buffer zone of Limpopo National Park is still poorly characterized. Several drivers stress that groundwater resources are susceptible to any change and, as a matter of fact, very vulnerable. Many rural villages rely entirely on groundwater abstraction for farming, irrigation and drinking water supply, domestic uses and groundwater for the bottling water industry (MacDonald et al. 2008, 2009; Farolfi and Gallego-Ayala 2013; Limaye 2017; Carvalho and Chaminé 2021; Andrei et al. 2021) (Fig. 2). Still, groundwater supplies are increasingly threatened by contamination by various sources, and their overexploitation makes it sometimes insufficient for human demand as for biological diversity conservation. Moreover, climate change is a growing up factor of pressure on groundwater resources availability and water quality protection.

Due to the complexity of the geological and hydrogeological framework within the SADC (Southern African Development Community) region, including Mozambique, groundwater quality varies considerably depending on different climatic regions, aquifer geological, lithological features and thickness (DEA 2015). That is why the priority is to ensure that their water resources, especially groundwater, are managed in a sound and equitable manner for local communities and supporting biodiversity conservation within a hydrogeoethical way.

\section{Geological and hydrogeological setting}

The African continent consists of a mosaic of old stable and crystalline crustal blocks, the so-called cratons. They are surrounded by a network of younger orogenic belts including deformed metamorphic rocks and granites, known as mobile belts. This scenario comes from the geological evolution of the Gondwana continent (Key 1992; Van Hinsbergen et al. 2011). In the setting of Gondwana, the geographic position of Mozambique makes this country a geologically important 


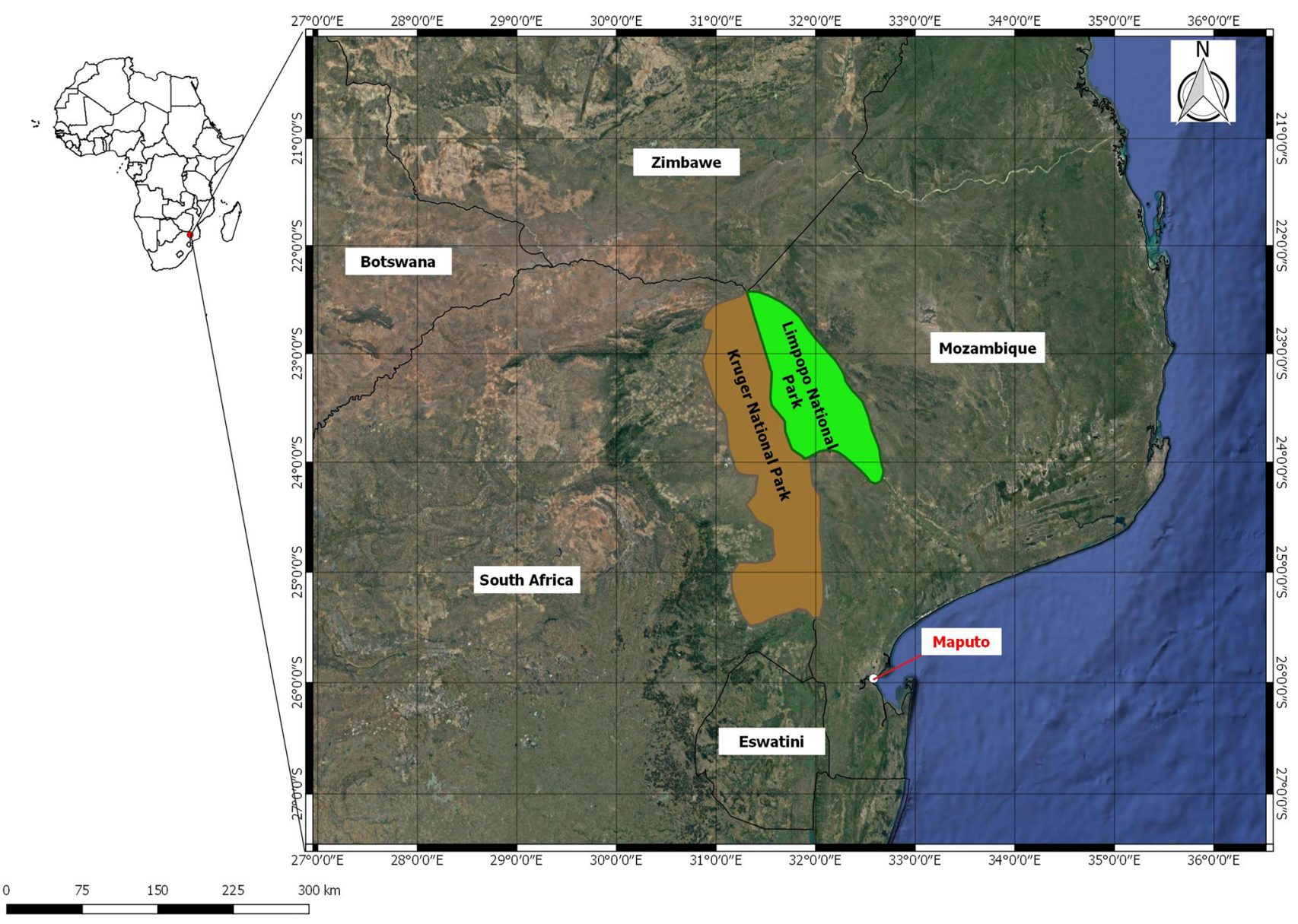

Fig. 1 Map of the Limpopo National Park Buffer Zone (Mozambique)

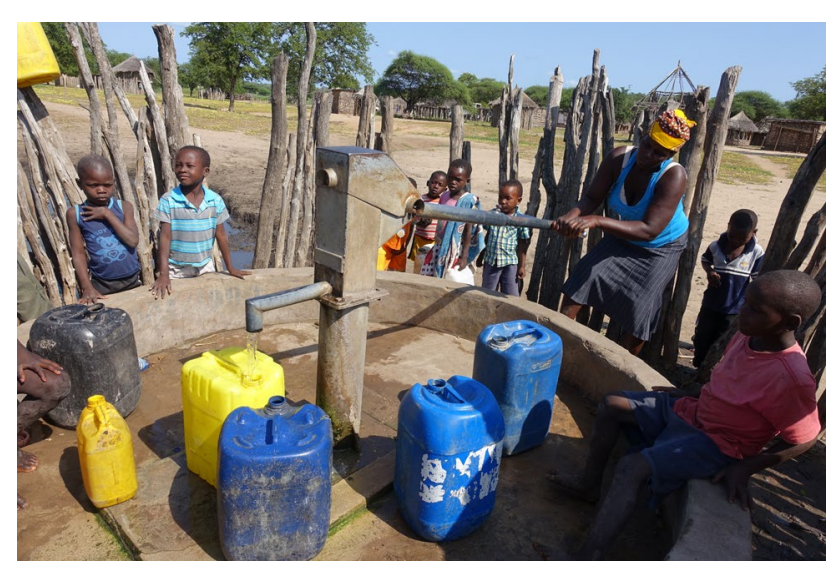

Fig. 2 Groundwater extraction in a village of the buffer zone of Limpopo National Park

region, particularly because it contains boundaries between cratons and mobile belt terrains. The crystalline basement of Mozambique belongs to three larger terrains: East, West and South Gondwana. These blocks collided and amalgamated during the Pan-African orogeny to form the Gondwana continent (Key 1992; Van Hinsbergen et al. 2011; Klimke et al. 2018). In southern and central Mozambique, the Phanerozoic rocks can be divided into the Karoo Supergroup (Permian-Jurassic) followed by a succession of Cretaceous and younger sedimentary formations. They are partly associated with the development of the East Africa Rift System. Phanerozoic sedimentary rocks of the Mozambique Basin occupy vast areas in southern Mozambique (Eales et al. 1984; Cox 1992; Van Hinsbergen et al. 2011; Klimke et al. 2018).

A geological setting of the study area is shown in Fig. 3. The Limpopo Basin is floored by Jurassic volcanic rocks and filled by Early to Middle Cretaceous and younger sedimentary rocks. The Mapai formation in the western part of the Gaza Province in southern Mozambique is divided into six parts characterized by calcareous siltstones, calcareous sandstones and calcareous conglomerates, locally calcified and oxidized (Förster 1975). The hydrogeology of the basin is dominated by the Limpopo Mobile Belt, with a high grade that lies in the collision zone between the Kaap Vaal craton and Zimbabwe with the Archean continental shield areas. Due to the metamorphism, these rocks have 


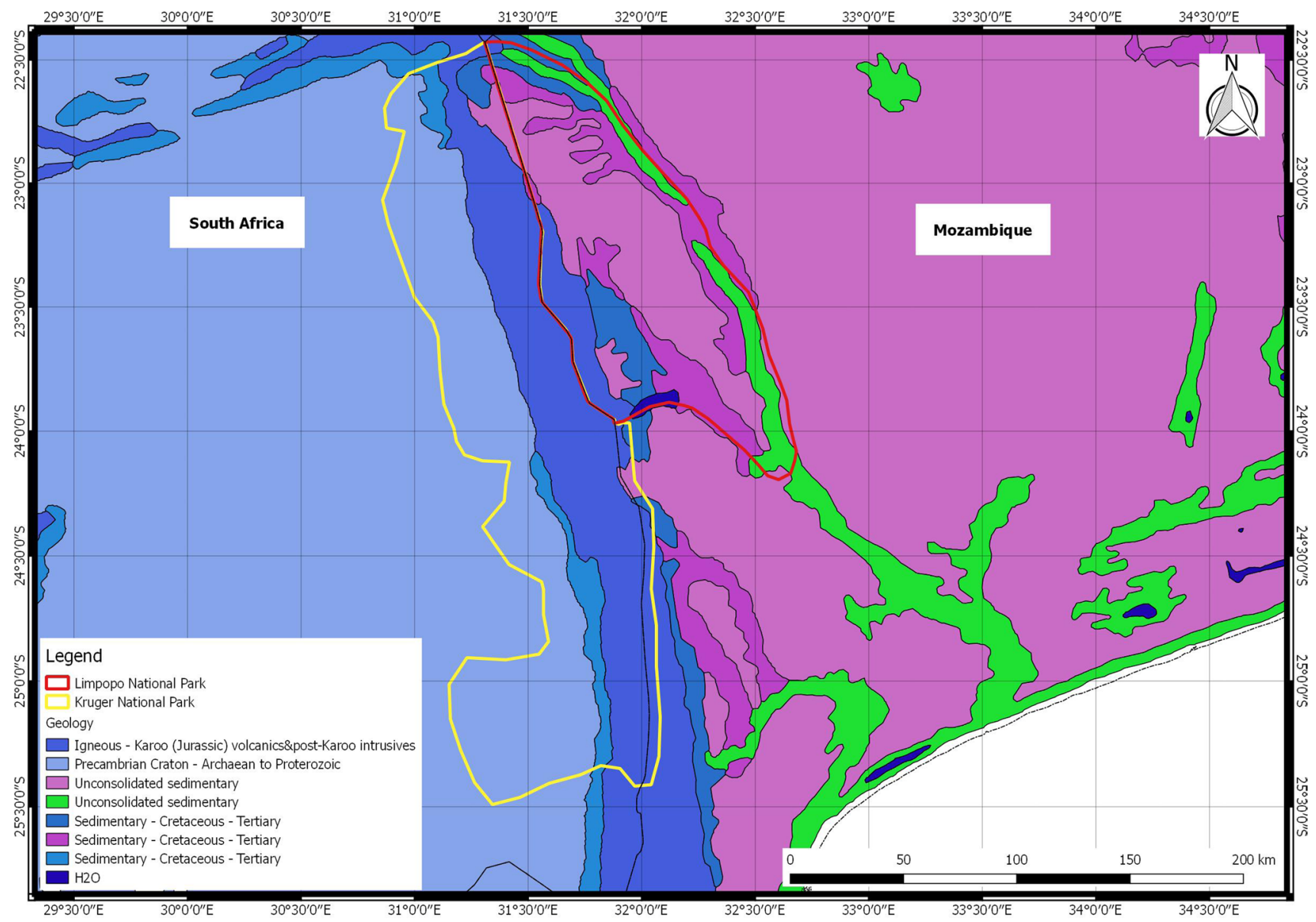

Fig. 3 Simplified geological map of study area (source U.S. Geological Survey, https://catalog.data.gov/dataset)

very low primary porosity or permeability (Farquharson and Bullock 1992; Wright 1992). The groundwater occurrence is restricted mainly to secondary features such as fault zones, joints, lithological and vein contacts (Owen and Madari 2010). From the hydrogeological point of view, the Karoo Volcanic rocks of the Limpopo Basin in Mozambique are fairly somewhat crystalline ones, and primary and secondary fractures are essential water-bearing features (Farquharson and Bullock 1992; Boroto 2001).

The aquifers are divided into separate lenticular units and are found in the deep alteration zone of the rocky substratum, at the contact zones between rocks of different types and faulted, fractured or crushed zones. The main hydrogeological units correspond roughly to geological formations. They are aquifers related to the crystalline basement complex, aquifers occurring in Karoo formations and aquifers related to post Karoo formations (Ferro and Bouman 1987). In the complex crystalline formation, aquifers have only local expression (Ferro and Bouman 1987). They provide low unit yields, rarely more than $2 \mathrm{~L} / \mathrm{s}$. Dug wells generally take advantage of a suspended aquifer on the top with a lateritic layer.

\section{Materials and methods}

\subsection{Rainfall monitoring network}

In the aim of contributing to the baseline knowledge of aquifers recharge and identifying which phenomena, i.e., climate change or drought cycles can be connected to it, the hydrogeological inverse budget (Civita et al. 1999) was applied to estimate the groundwater recharge, referred to the study area for different rainfall scenarios. They have been considered, on the first, the existing meteorological station network inside and in the surroundings of Limpopo National Park area and its buffer zone. Unfortunately, the Limpopo National Park does not have sufficient coverage of rainfall records for its scale basin-wide. The main operational rainfall stations are located in the Southern part of Mozambique as is reported in Table 1 and shown in Fig. 4 (Vitale et al. 2017a).

Unfortunately, data collections obtained from the meteorological stations by Mozambique are not enough to create historical rainfall, which could not be statistically representative of climate evolution for Limpopo National Park. 
Table 1 Current rainfall monitoring network (after INAM 2016)

\begin{tabular}{llll}
\hline Meteorological Stations & \multicolumn{2}{l}{ Period of observations } & Functionality \\
\hline Massangena & 1960 & 2015 & Operative \\
Chicualacuala & 1961 & 2003 & Inoperative \\
Chigubo & 1961 & 1978 & Inoperative \\
Mabalane & No data & No data & Operative \\
Massingir & 1961 & 2014 & Operative \\
Funhalouro & $1951 / 2003$ & $1980 / 2007$ & Inoperative \\
Chibuto & 1965 & 2014 & Inoperative \\
Bilene-Macie & 1965 & 2014 & Operative \\
Xai-Xai & 1951 & 2016 & Operative \\
Panda & 1951 & 2016 & Operative \\
Massinga & $1951 / 2003$ & $1980 / 2016$ & Operative \\
Ndindiza & 2006 & 2016 & Operative \\
\hline
\end{tabular}

Therefore, data from 21 stations (Table 2) with 64 years of measurements from the Kruger National Park's meteorological stations network were used (Fig. 5) (Sappa et al. 2018). The Fig. 5 shows the Kruger National Park's meteorological stations network considered in this paper.

\subsection{The methodology of inverse hydrogeological water technique}

The groundwater recharge, referred to the study area, has been assessed by applying the Inverse Hydrogeological Water Balance, a spatial spread data method for evaluating aquifer recharge. The Inverse Hydrogeological Water Balance (Civita et al. 1999) was applied to estimate the average annual active recharge (i.e. the effective infiltration-I) for the Limpopo National Park area, with a GIS-based mapping approach to different ranges of years. For groundwater recharge evaluation, this procedure has the advantage of not needing any information on runoff, which is not available in the study area. The application of this method involves a series of steps, which are presented in the flowsheet of Fig. 6 (Civita and De Maio 2001).

Therefore, according to flowchart in Fig. 6, the study area has been divided into FSE of $1 \mathrm{~km}^{2}(1 \times 1 \mathrm{~km})$, the smallest dimension to give a reliable representation of morphological features of the study area. For this, it was considered a Digital Elevation Model (DEM) all over Kruger and Limpopo National Park area, built by

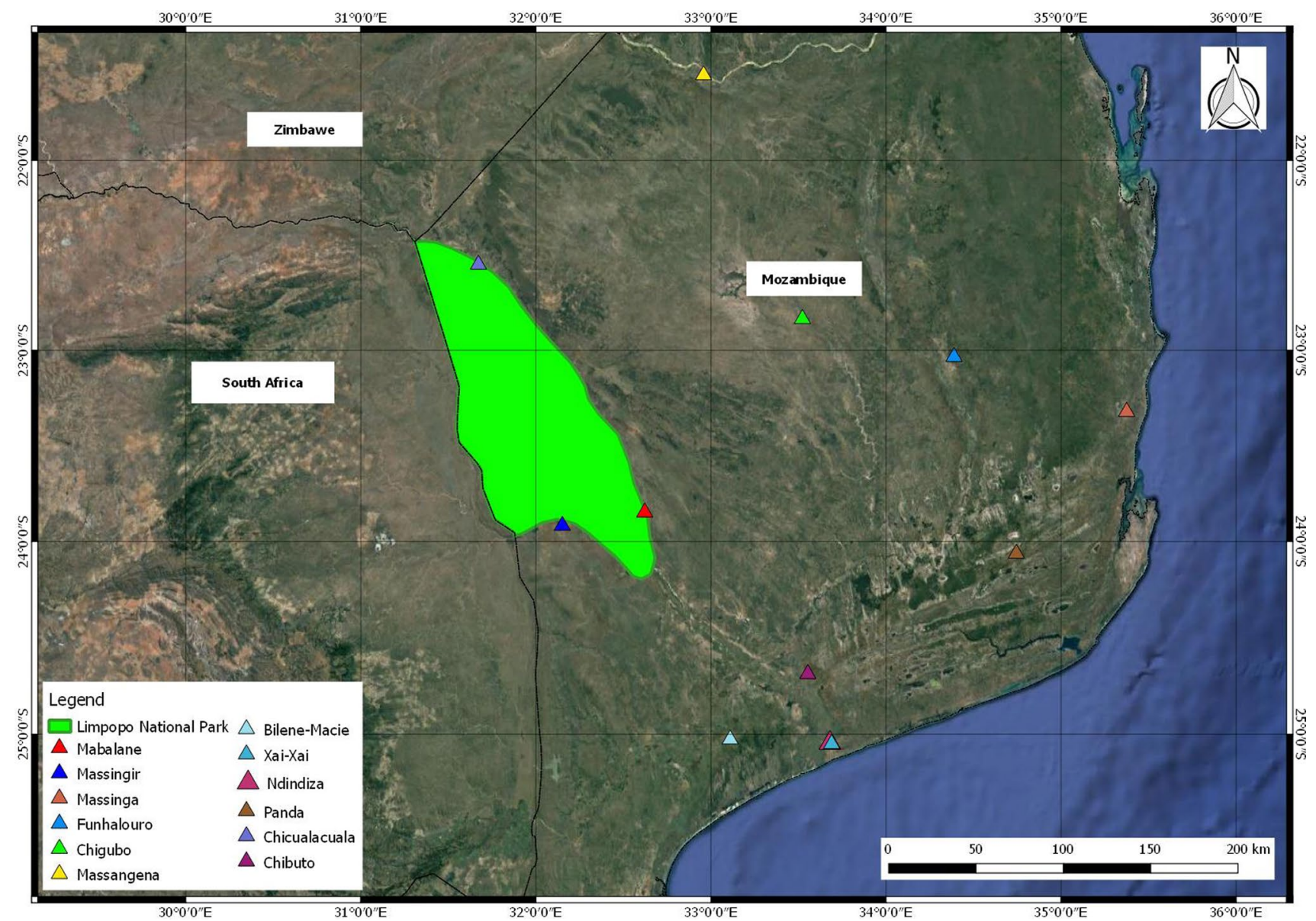

Fig. 4 Map of rainfall monitoring stations in Southern part of Monzambique 
Table 2 The 21 stations of the Kruger National Park area

\begin{tabular}{|c|c|c|c|c|c|}
\hline \multirow[t]{2}{*}{ Meteorological stations } & \multirow[t]{2}{*}{ Abbreviation } & \multicolumn{2}{|l|}{ UTM } & \multirow{2}{*}{$\begin{array}{l}\text { Altitude (m } \\
\text { a.s.1.) }\end{array}$} & \multirow[t]{2}{*}{ Year Rain } \\
\hline & & East (X) & North (Y) & & \\
\hline Crocodile Bridge & KRO & $388,865.049$ & $7,195,400.074$ & 166 & 1956-2014 \\
\hline Houtboschrand & $\mathrm{HOU}$ & $364,730.525$ & $7,334,147.063$ & 242 & \\
\hline Kingfisherspruit & KFI & $342,729.090$ & $7,294,024.974$ & 418 & 1956-2014 \\
\hline Letaba & LET & $354,918.906$ & $7,361,395.020$ & 230 & 1956-2018 \\
\hline Lower-Sabie & OSA & $390,750.923$ & $7,221,110.698$ & 180 & \\
\hline Phalaborwa & PHA & $315,016.729$ & $7,351,013.311$ & 415 & 1956-2018 \\
\hline Pretoriuskop & PRE & $325,558.058$ & $7,215,312.511$ & 587 & 1956-2014 \\
\hline Punda Maria & PUN & $296,444.252$ & $7,489,385.095$ & 460 & 1956-2018 \\
\hline Satara & SAT & $376,276.456$ & $7,301,914.212$ & 267 & 1956-2014 \\
\hline Shingwedzi & SHI & $339,947.651$ & $7,443,580.099$ & 272 & 1956-2018 \\
\hline Skukuza & SKZ & $357,467.637$ & $7,235,290.841$ & 280 & 1956-2014 \\
\hline Tshokwane & TSH & $384,111.931$ & $7,258,634.317$ & 252 & 1956-2014 \\
\hline Berg En Dal & & $343,900.461$ & $7,187,099.476$ & 350 & \\
\hline Mahlangeni & MAH & $311,159.387$ & $7,383,696.289$ & 300 & 1956-2018 \\
\hline Malelane & MAL & $349,981.920$ & $7,182,128.550$ & 320 & 1956-2014 \\
\hline Mooiplaas & MOP & $336,609.402$ & $7,398,989.116$ & 368 & 1956-2018 \\
\hline Nwanetsi & NWA & $396,395.644$ & $7,295,454.522$ & 180 & \\
\hline Olifants & OLI & $372,035.176$ & $7,344,901.345$ & 220 & \\
\hline Stolznek & STO & $338,224.922$ & $7,198,110.34$ & 480 & \\
\hline Vlakteplaas & VLA & $318,436.002$ & $7,469,727.302$ & 341 & \\
\hline Woodlands & WOO & $316,521.346$ & $7,430,839.311$ & 337 & \\
\hline
\end{tabular}

registering one point any $90 \mathrm{~m}^{2}$ of surveying and coming from the elaboration of data, obtained from CGIAR-CSI (http://srtm.csi.cgiar.org/). Any FSE has been represented by an altitude value for further elaboration, especially meteorological ones, from applying a special script included in Quantum GIS software. Geological information, considered for the hydrogeological characterization of the area, has been gathered from the Soil and Terrain SOTER database (ISRIC 1991; see details in: https://data. isric.org), which gave a detailed description of the Limpopo National Park area. The SOTER database includes the outcropping rock formations, reported in Table 3. Anyway, the information are helpful for the potential infiltration estimation of any FSE.

Table 3 shown the type of outcropping rock masses and the Potential Infiltration Factor $\left(\chi_{s}\right)$, taking into account properties of geological formations gathered from the SOTER (Sappa et al. 2015). Consequently, to match information from the geological map with other data referred to the study area, a digital geological map was elaborated using the open-source software Quantum GIS. Considering the lithostratigraphic units in the study area, obtained from SOTER, were simplified the map and emphasized hydrogeological features.

\section{Results and discussion}

In the aim of well considering any effects on the area under study, due to climate change factors, the key step of the Hydrogeological Inverse Budget (Civita and De Maio 2001) has been the setup of a relationship between rainfalls and altitude inside the Limpopo National Park area, as shown in flowchart in Fig. 6. The precipitation data were then considered, coming from the network of meteorological stations in the Kruger National Park area, consisting of six meteorological stations for 64 years of measurements: Punda Maria, Shingwedzi, Mooiplaas, Mahlangeni, Letaba and Phalaborwa. This is because some of them are located at approximately the same latitude as the Limpopo National Park area and they represent better the altitude distribution inside the Park.

First, the Annual Average Precipitation (AAP) was calculated for each rainfall station, referred to the historical series 1956-2018 of the six meteorological stations which, unfortunately, is not strictly continuous. Therefore, a rainfall-altitude relationship has been calculated and it is shown in Fig. 7. 


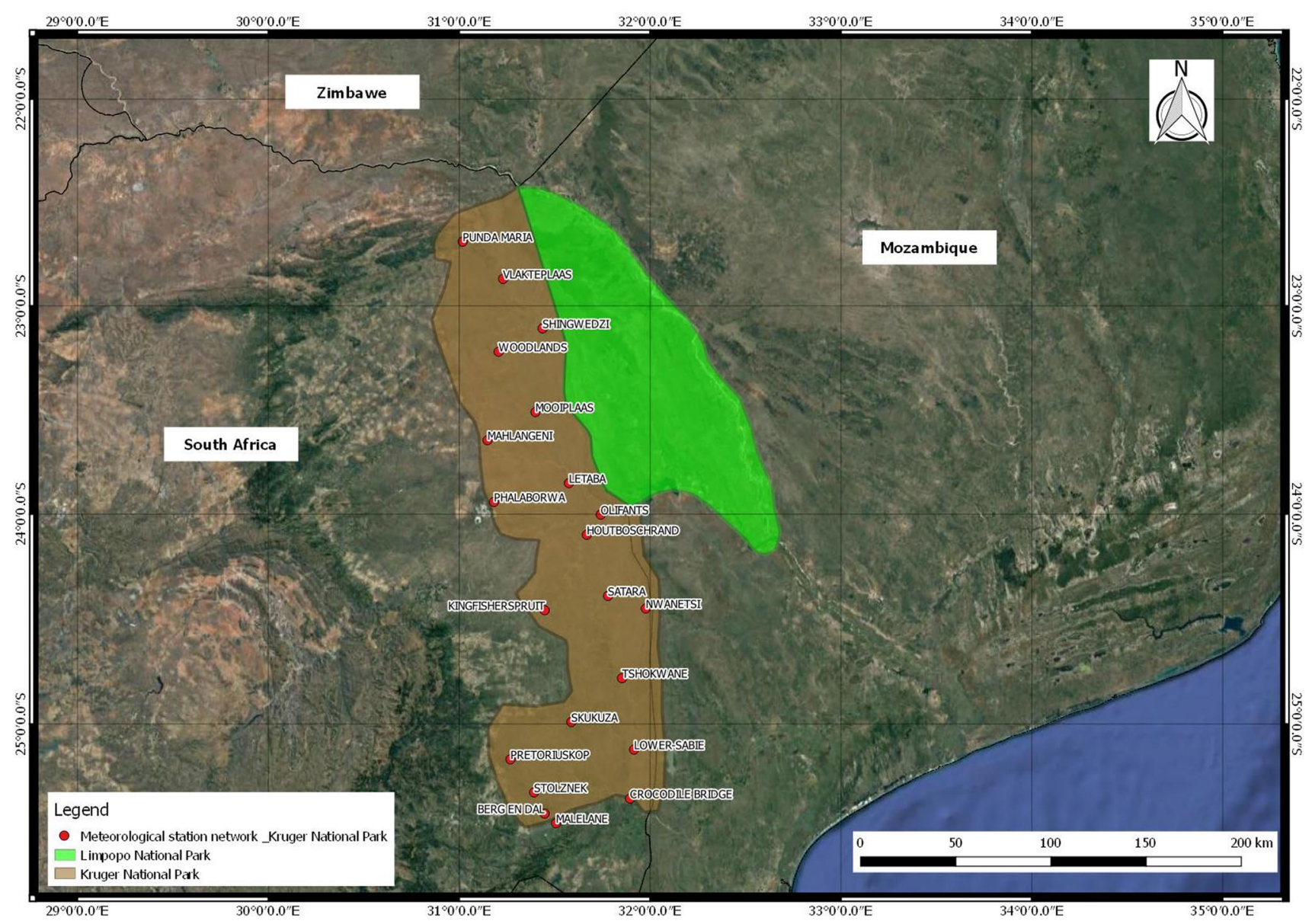

Fig. 5 Meteorological station network inside Kruger National Park area

Fig. 6 Flow-chart of the inverse hydrogeological water balance

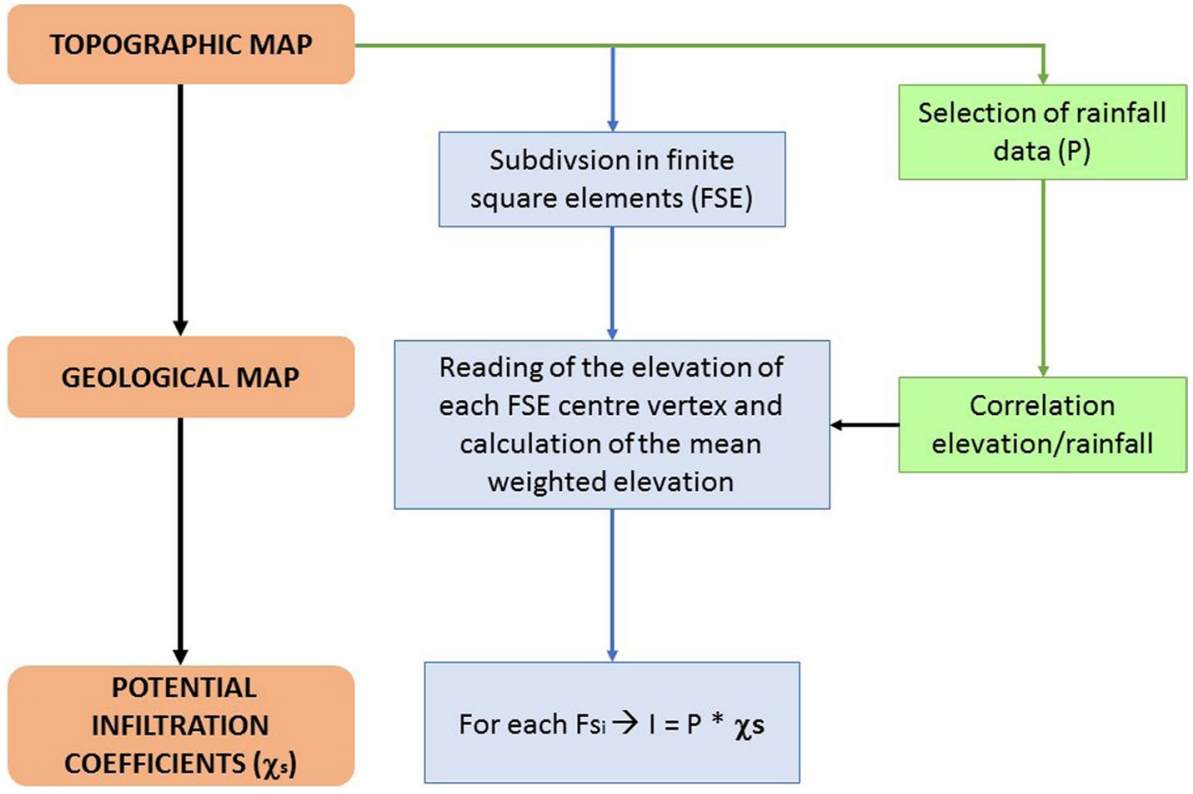


Table 3 Lithological description of the Limpopo National Park (Soil and Terrain Database for Southern Africa-SOTER: https://data.isric.org/)

\begin{tabular}{llll}
\hline Major Class & Group & Type & $\begin{array}{c}\text { Potential } \\
\text { infiltration } \\
\text { factor- }-\chi_{s}\end{array}$ \\
\hline Unconsolidated & UF & Fluvial: sediments generally consisting of gravel and sand or silt and clay & 0.1 \\
& UC & Colluvial: massive to moderately well stratified unsorted to poorly sorted sediments & 0.25 \\
& UE & Eolian: sediments consisting of medium to fine sand and coarse silt particle sizes & 0.1 \\
Basic Igneous Rock & IB2 & Basalt & 0.3 \\
Clastic sediments & SC2 & Sandstone, greywacke, arkose & 0.15 \\
& SO2 & Marl and other Silt & 0.1 \\
\hline
\end{tabular}

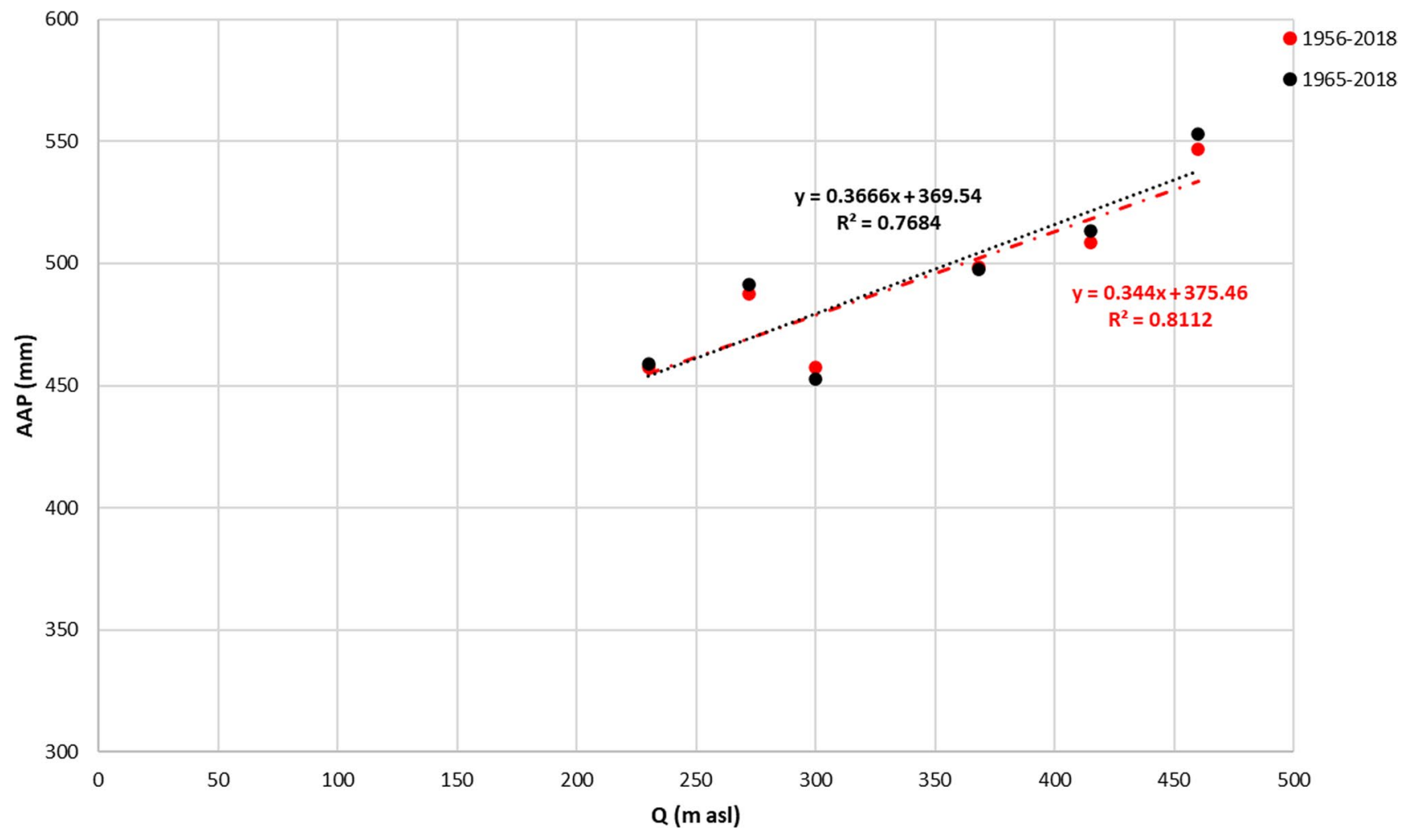

Fig. 7 Linear regression line rainfall altitude (1956-2018 in red) and (1965-2018 in black)

The correlation rainfall altitude in Fig. 7, referred to the six stations inside the Kruger National Park, has been the first step to assess the effective infiltration action based on the outcropping lithologies. According to this relationship, it has been possible to set up the following expressions, which allows having a rainfall value for any altitude:

$\mathrm{AAP}(\mathrm{mm})=0.344 \times Q(\mathrm{~m}$ a.s.1. $)+375.46$ for $1956-2018$

$\mathrm{AAP}(\mathrm{mm})=0.367 \times Q(\mathrm{~m}$ a.s.l. $)+369.54$ for $1965-2018$

where: AAP is the Average Annual Precipitation (mm); $Q$ is the altitude ( $\mathrm{m}$ a.s.1.)
This approach drove to an estimation of precipitations distribution in the study area (Fig. 6). So, this highlights that between 1956 and 2018, inside the Limpopo National Park area, the Average Annual Precipitation had a maximum value of about $600 \mathrm{~mm}$ in the Northwest and a minimum value of about $400 \mathrm{~mm}$ in the Southeast. As a validation of the applied extrapolation on the meteorological data from the Kruger National Park area to the Limpopo National Park, it is interesting to note that previous studies using meteorological data referred to the entire Mozambique very similar values (Vitale et al. 2017a).

In the aim of estimating climate change effects on precipitations and, consequently, on groundwater recharge, they 

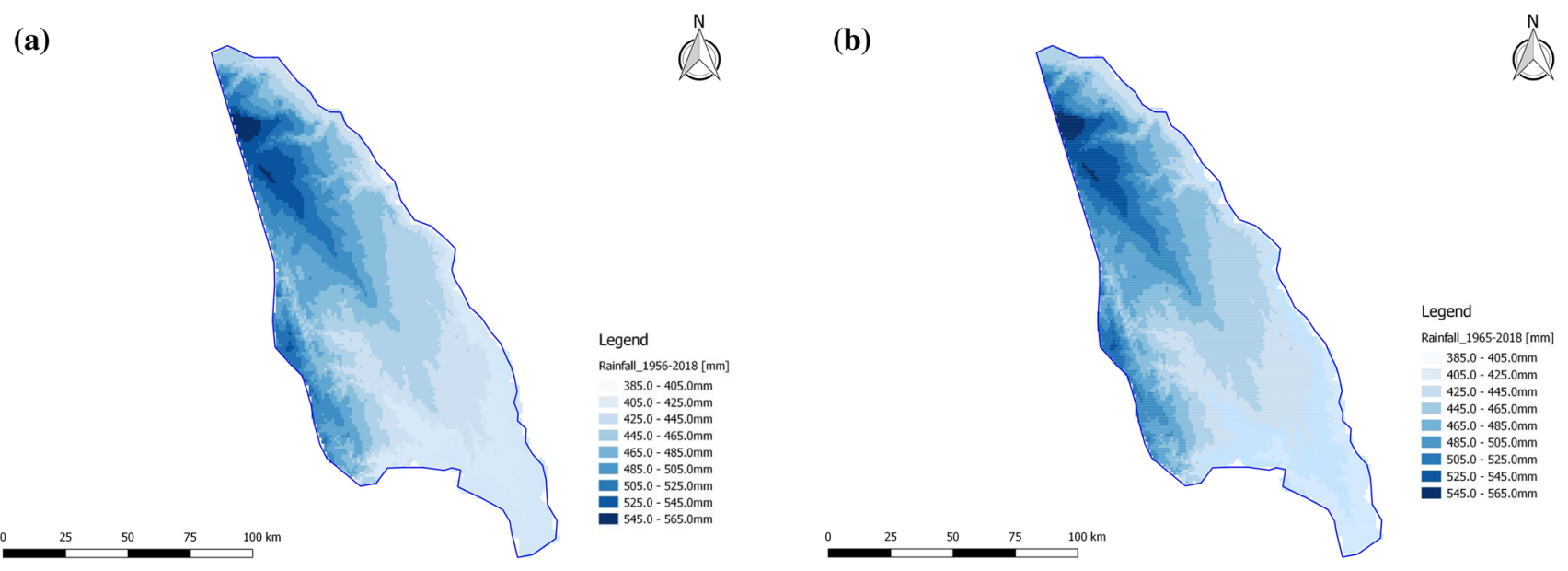

Fig. 8 Map of the rainfall in the Limpopo National Park: a 1956-2018; b 1965-2018

Table 4 Meteorological stations considered for rainfall characterization between 1965 and 2014

\begin{tabular}{|c|c|c|c|c|c|}
\hline \multirow[t]{2}{*}{ Meteorological stations } & \multirow[t]{2}{*}{ Abbreviation } & \multicolumn{2}{|l|}{ UTM } & \multirow{2}{*}{$\begin{array}{l}\text { Altitude } \\
\text { (m a.s.l.) }\end{array}$} & \multirow{2}{*}{$\begin{array}{l}\text { AAP }_{1965-2014} \\
(\mathrm{~mm})\end{array}$} \\
\hline & & East $(\mathrm{X})$ & North (Y) & & \\
\hline Letaba & LET & $354,918.906$ & $7,361,395.02$ & 230 & 459 \\
\hline Phalaborwa & PHA & $315,016.729$ & $7,351,013.311$ & 415 & 513 \\
\hline Punda Maria & PUN & $296,444.252$ & $7,489,385.095$ & 460 & 553 \\
\hline Shingwedzi & SHI & $339,947.651$ & $7,443,580.099$ & 272 & 491 \\
\hline Mahlangeni & MAH & $311,159.387$ & $7,383,696.289$ & 300 & 452 \\
\hline Mooiplaas & MOP & $336,609.402$ & $7,398,989.116$ & 368 & 498 \\
\hline
\end{tabular}

Table 5 Evolution of relationships between rainfalls and altitude from 1965 to 2018

\begin{tabular}{ll}
\hline Decade & Altitude-rainfall relationship \\
\hline $1965-1974$ & AAP $(\mathrm{mm})=0.355 \times Q(\mathrm{~m})+379.09$ \\
$1975-1984$ & AAP $(\mathrm{mm})=0.591 \times Q(\mathrm{~m})+350.71$ \\
$1985-1994$ & AAP $(\mathrm{mm})=0.408 \times Q(\mathrm{~m})+272.83$ \\
$1994-2004$ & AAP $(\mathrm{mm})=0.423 \times Q(\mathrm{~m})+431.37$ \\
$2005-2014$ & AAP $(\mathrm{mm})=0.364 \times Q(\mathrm{~m})+340.65$ \\
$2015-2018$ & AAP $(\mathrm{mm})=0.3789 \times Q(\mathrm{~m})+229.24$ \\
\hline
\end{tabular}

have been considered a different range of years, included in the historical series, going from 1965 to 2018, as this range of years takes to a very similar evaluation of rainfalls distribution of 1956-2018. The spatial distribution of precipitations is illustrated in Fig. 8a, b for about 50 years. Due to the data availability, they have been considered meteorological stations included in Table 4 to set up relationships AltitudeAAP for any considered station.

Afterwards, the range of time from 1965 to 2018 has been divided into decades to evaluate climate change impacts better. Then the method was applied to evaluate spatial rainfall distribution, referred to the decades represented in Table 5, where they have also represented the relationships between rainfalls and altitude.

It is interesting to outline that there is no evidence of homogeneous rainfall evolution in this time range. Therefore, it can suppose that it is under a regular climate change trend. It is possible to say, on the other side, that the considered decades (from 1965 to 2018) have been characterized by a rainfall decreasing, except for one, going from 1995 to 2004. Figure 9 shows the trend of maximum and minimum values of rainfall in the considered range of years.

Figure 9 shows a quite peculiar behaviour for minimum and maximum values of rainfall, with a sensitive decrease from 1965 to 1994 decade to 2005-2014. In particular, Fig. 9 shows that in the first decade, 1965-1974, the minimum value was $396 \mathrm{~mm} / \mathrm{y}$, while the minimum one referred to the last decade, going from 2005 to 2014, has been $255 \mathrm{~mm} / \mathrm{y}$. The same comparison made between maximum values, referred to the same 2 decades, gives the most considerable value of rainfall, estimated for the decade 1965-1974, to be $567 \mathrm{~mm} / \mathrm{y}$, and the same one, estimated for 2005-2014, is $433 \mathrm{~mm} / \mathrm{y}$. It means that between these 2 decades, in the range of about 64 years, they have been lost about $30 \%$ of rainfalls, referred to the study area. 


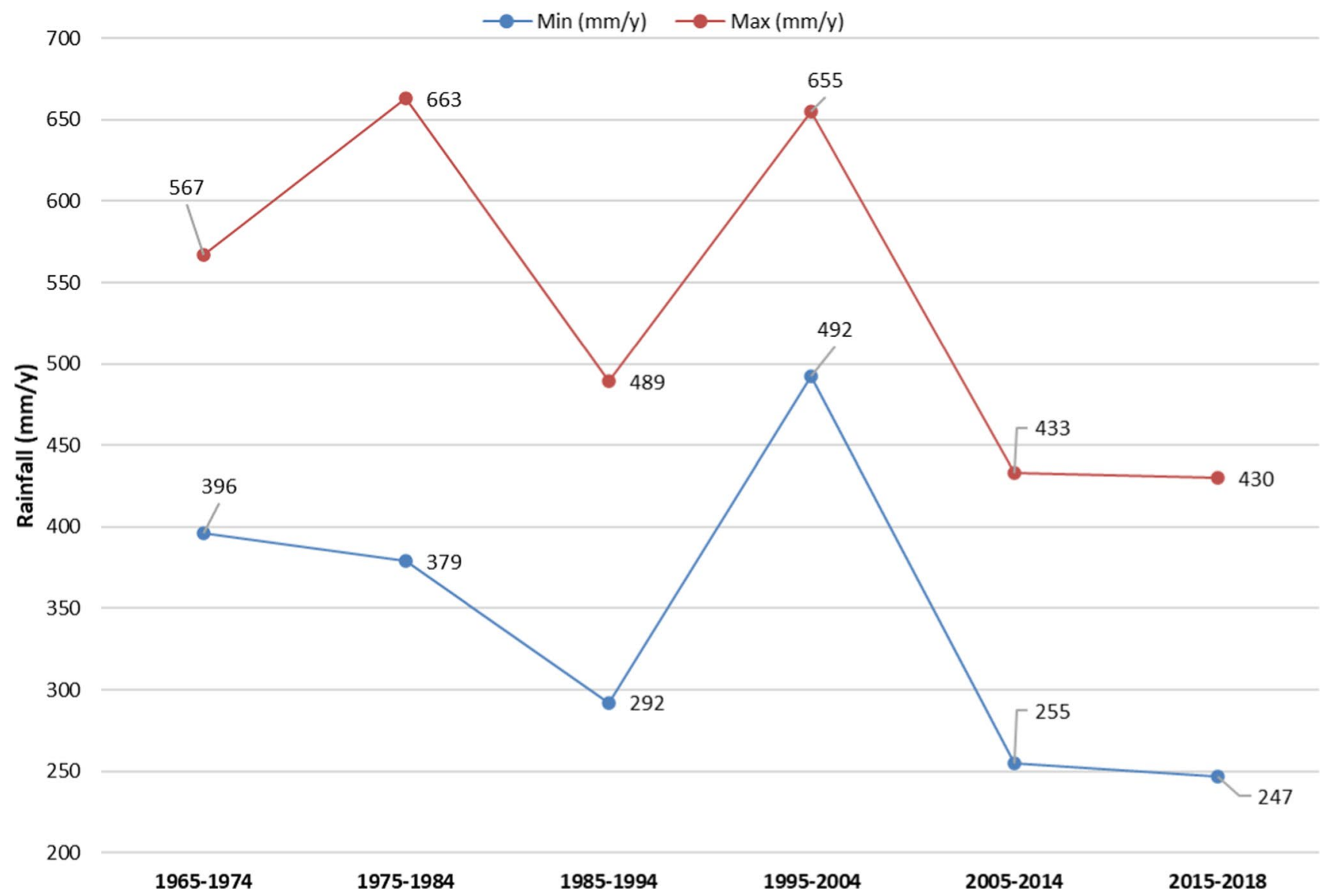

Fig. 9 Trend of maximum and minimum values of rainfall in the considered range of years

The calculation of effective infiltration have been made by matching rainfall estimation and outcropping rock mass hydrogeological properties to estimate groundwater recharge in Limpopo National Park and buffer zones. The value of the effective infiltration to assign to each cell is a linear function of the rainfall, whose distribution of the Average Annual Pluviometric Modulus has been calculated, applying the previously described function related to altitude data. The effective infiltration $(I)$ has been calculated starting from rainfall $(P)$ values and Potential Infiltration Factor $\left(\chi_{s}\right)$, shown in Table 3, using the formula (3):

$I_{\text {eff }}=P \times \chi_{s}$

The choice of $\chi_{s}$ has been made considering the specific guideline offered by the method authors as the experience carried out by the authors in previous studies (Sappa et al. 2015). The applied methodology determined the yearly average infiltration rate, given in millimetres, for each FSE of the discretization grid in the study area. The hydrological balance, performed for the study area, assessed the effective infiltration, considering the mean precipitation data, referred to different periods from 1956 to 2014.
Table 6 Summary of maximum and minimum values of infiltration in the considered range of years

\begin{tabular}{lll}
\hline Range of years & Max $(\mathrm{mm} / \mathrm{y})$ & Min $(\mathrm{mm} / \mathrm{y})$ \\
\hline $1965-1974$ & 161 & 32 \\
$1975-1984$ & 183 & 37 \\
$1985-1994$ & 136 & 27 \\
$1995-2004$ & 185 & 37 \\
$2005-2014$ & 120 & 24 \\
$2015-2018$ & 119 & 22 \\
\hline
\end{tabular}

Moreover, as it has been done to evaluate rainfall evolution, it has considered the outcropping lithology (Sappa et al. 2015) coming from the SOTER for Southern Africa referring to the Limpopo National Park. To better evaluate infiltration distribution all over the area under study, in Table 6, they are reported results referred to the maximum, and minimum infiltration values gathered for any considered range of years. As the minimum calculated value is always zero, it preferred to report the maximum value of the lowest class of infiltration, because it is representative for minimum values, as shown in the Fig. 8. 
It is interesting to highlight two aspects of these results. The first one is the slight part of precipitations, which becomes infiltration, in the study area. This is due to the very low hydraulic conductivity of outcropping rock masses. Secondly, as it has been noticed for rainfall evolution within the considered range of years, there is no regular decreasing trend in infiltration. However, in this case, it is evident that in the last considered years, from 2005 to 2018 , there was a sensitive decrease in infiltrations, as in comparison with the previous decade, from 1995 to 2004, and for the whole considered period, from 1965 to 2018 .

At the end of its application, the Hydrogeological Inverse Budget leads to an evaluation of groundwater recharge, expressed, not only as infiltration values of $\mathrm{mm}$, referred to any singular FSE, but also by the multiplication of any single FSE infiltration value by the value of its area it is possible to obtain the infiltration value in terms of annual volume. The addition of every value, referred to each FSE of the grid, provided the estimation of the aquifer annual average recharge as average annual volume

A.R. $\left(\frac{\mathrm{m}^{3}}{\text { year }}\right)=\left(\sum_{i=1}^{N} I_{\mathrm{EFQ}_{\mathrm{i}}}\right) \times A_{\mathrm{EFQ}_{\mathrm{i}}}$

where:

(a)

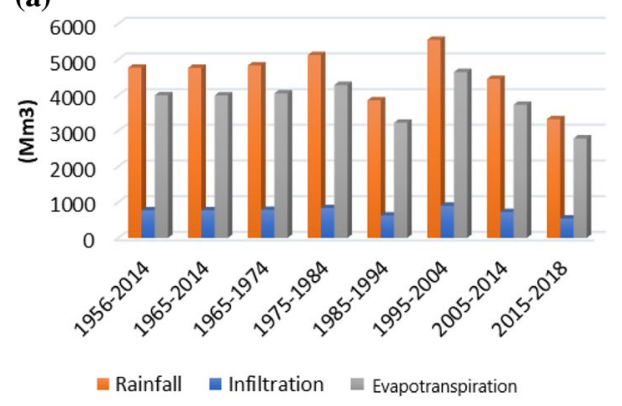

(b)

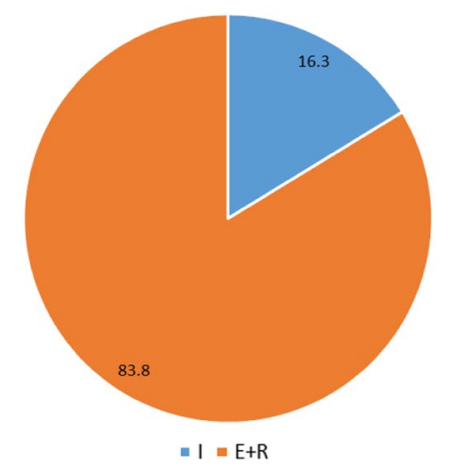

Fig. 10 Trend of rainfall, infiltration and evapotranspiration in the considered range of years (a); rate of infiltration $(I)$ and evapostranspiration + rainfall (b)
A.R. is the annual active recharge;

$\mathrm{I}_{\mathrm{EFQi}}$ is the effective infiltration of the i-th FSE;

$\mathrm{A}_{\mathrm{EFQi}}$ is the area of the $\mathrm{i}$-th FSE

The results from the groundwater recharge computation in the Mozambique Limpopo National Park area referred to as different years are represented in Fig. 10. They confirm what already noticed for the elaboration of data referred to precipitations and infiltration rate, referred to the last 64 years and, specifically, the sensitive decrease registered in the previous decades. Thus, there is no evidence of a decreasing trend in groundwater recharge, referred to the considered time range. However, on the other side, there is a very remarkable difference among groundwater recharge estimation, referred to different considered decades (Table 7). This highlights that a very hard loss in groundwater recharge has been registered in the last decade (from 2005 to 2014), which is probably a consequence of climate change in this area. This fact, coupled with the meager percentage represented by infiltration in comparison with precipitation calculated to the last 64 years (Fig. 10), make this area susceptible to climate change effects on groundwater availability.

The results coming from the calculation of groundwater recharge in Limpopo National Park area, referred to different range of years, are represented in Fig. 10. Figure 10b shows that in the last 64 years there was a sensitive decrease of infiltration rate, with an average value about equal to $16.3 \%$. An improvement of surface water management could be suggested in this area. The Limpopo National Park area is very close to Massingir Lake, made by constructing a vital dam built along the Oliphant River to store millions of cubic metres of water. Part of this large volume could be managed by constructing an adequate water network or channels for feeding communities living in the buffer zone and for sound conservation of biodiversity in the Limpopo National Park area.

\section{Conclusions}

This work has presented the results of applying the Hydrogeological Inverse Budget to the Limpopo National Park area by sharing meteorological data from historical series

Table 7 Groundwater recharge estimation (1965-2018)

\begin{tabular}{lc}
\hline Range of years & $\Delta I(\%)$ \\
\hline $1965-1974$ & 1 \\
$1975-1984$ & 7 \\
$1985-1994$ & -27 \\
$1995-2004$ & 35 \\
$2005-2014$ & -45 \\
$2015-2018$ & -30 \\
\hline
\end{tabular}


collected in the Kruger National Park, close to the area under study. This study evaluated groundwater recharge in the Limpopo National Park area (Mozambique) for biodiversity conservation and supported local dispersed communities in its buffer zone because of climate variability. On the whole, our results are interesting, at least for two aspects. First, they are significant to support biodiversity conservation and for local communities who still live in the village in the buffer zone of the Limpopo National Park area. Second, it is highlighted that the area understudy faced a sensitive climate change in the last fifteen years. This means that precipitations are sensitively decreasing, with a consequent decrease also in groundwater availability. In addition, it is more meaningful in the area under investigation that indicates that the infiltration rate of precipitations is very poor due to the low hydraulic conductivity of rock masses in the area under study. The authors are aware of having worked with very poor data. Still, they seem to be enough to highlight those locally dispersed communities living in this area and its biodiversity conservation suffer from climate change effects, and it is crucial to go on with more detailed studies concerning water supply in this region. Lastly, to improve the water resources supply of dispersed communities and surface water management, and adequate water network could be constructed to use the millions of cubic metres of water of the dam built along the Oliphant River.

Acknowledgements The Italian Ministry of Foreign Affairs funds this research within the framework of the SECOSUD Phase II in the South African Department of Environmental Affairs (DEA) - "Conservation and equitable use of biological diversity in the Southern African Development Community (SADC) region".

Open Access This article is licensed under a Creative Commons Attribution 4.0 International License, which permits use, sharing, adaptation, distribution and reproduction in any medium or format, as long as you give appropriate credit to the original author(s) and the source, provide a link to the Creative Commons licence, and indicate if changes were made. The images or other third party material in this article are included in the article's Creative Commons licence, unless indicated otherwise in a credit line to the material. If material is not included in the article's Creative Commons licence and your intended use is not permitted by statutory regulation or exceeds the permitted use, you will need to obtain permission directly from the copyright holder. To view a copy of this licence, visit http://creativecommons.org/licenses/by/4.0/.

\section{References}

Abrunhosa M, Chambel A, Peppoloni S, Chaminé HI (2021) Preface: advances in geoethics and groundwater management: theory and practice for a sustainable development. Proceedings of the 1st congress on geoethics and groundwater management, Porto, Portugal 2020. Advances in science, technology and innovation. Springer, Cham, pp 21-26

Andrei F, Barbieri M, Muteto PV, Ricolfi L, Sappa G, Vitale S (2021) Water resources management under climate change pressure in
Limpopo National Park Buffer Zone. In: Abrunhosa M, Chambel A, Peppoloni S, Chaminé HI (eds) Advances in geoethics and groundwater management: theory and practice for a sustainable development. Proceedings of the 1st Congress on Geoethics and Groundwater Management, Porto, Portugal 2020. Advances in science, technology and innovation. Springer, Cham, pp 129-132

Barbieri M, Ricolfi L, Vitale S, Muteto PV, Nigro A, Sappa G (2019) Assessment of groundwater quality in the buffer zone of Limpopo National Park, Gaza Province, Southern Mozambique. Environ Sci Pollut Res 26(1):62-77. https://doi.org/10.1007/ s11356-018-3474-0

Boroto RAJ (2001) Limpopo River: steps towards sustainable and integrated water resources management. Proc Sixth IAHS Sci Assem Maastricht 268:33-39

Carvalho JM, Chaminé HI (2021) Over fifty years of hydrogeological practice and geoethics: an intergenerational view of a changing world. In: Abrunhosa M, Chambel A, Peppoloni S, Chaminé HI (eds) Advances in geoethics and groundwater management: theory and practice for a sustainable development. Proceedings of the 1st congress on geoethics and groundwater management, Porto, Portugal 2020. Advances in science, technology and innovation series. Springer, Cham, pp 297-303

Civita M, De Maio M (2001) Average groundwater recharge in carbonate aquifers: a GIS processed numerical model. In: VII Conference on Limestone Hydrology and Fissured Media, Besançon, France, p 93-100

Civita M, De Maio M, Vigna B (1999) Una metodologia per la valutazione della ricarica attiva degli acquiferi. In: Atti $3^{\circ}$ Convegno Nazionale Sulla Protezione e Gestione delle Acque Sotterranee, Quaderni di Geologia applicata, Vol 1 Pitagora Editrice Bologna, p 1.291-1.303

Cox KG (1992) Karoo igneous activity and the early stages of the break-up of Gondwanaland. In: Storey BC, Alabaster T, Pankhurst RJ (eds) Magmatism and the causes of continental break-up, 68th edn. Geological Society, London, pp 137-148. https://doi.org/10. 1144/GSL.SP.1992.068.01.09

DEA-South African Department of Environmental Affairs (2015) Towards the coherent and synergistic implementation of the Rio Conventions in the Limpopo Basin: promoting policy coherence and integrated finance for sustainable land management. Italian Development Cooperation (IDC) and Global Mechanism (GM) of the United Nations Convention to Combat Desertification (UNCCD), Workshop Report, Cape Town, South Africa (Unpublished Report)

Eales HV, Marsh JS, Cox KG (1984) The Karoo igneous province: an introduction. In: Erlank AJ (ed) Petrogenesis of the volcanic rocks of the Karoo Province, 13th edn. Geological Society Special Publication of South Africa, Karoo, pp 1-26

FAO (2004) Drought impact mitigation and prevention in the Limpopo river basin. Land and Water Discussion Paper 4, Food and Agriculture Organization of the United Nations (FAO), Rome, Italy. https://www.preventionweb.net/files/1879_VL102146.pdf. Accessed Sep 2021

Farolfi S, Gallego-Ayala J (2013) Domestic water access and pricing in urban areas of Mozambique: between equity and cost recovery for the provision of a vital resource. Int J Wat Resour Dev 30(4):728-744

Farquharson FAK, Bullock A (1992) The hydrology of basement complex regions of Africa with particular reference to southern Africa. In: Wright EP, Burgess WG (eds) Hydrogeology of crystalline basement aquifers, 66th edn. Geological Society, London, pp 59-76

Ferro BPA, Bouman D (1987) Explanatory notes of the Hydrogeological Map of Mozambique, scale 1:1 000 000. UNICEF, Maputo

Förster R (1975) The geological history of the sedimentary basin of southern Mozambique, and some aspects of the origin of the 
Mozambique channel. Palaeog Palaeoclim Palaeoecol 17(4):267287. https://doi.org/10.1016/0031-0182(75)90002-4

ISRIC (1991) The SOTER manual procedure for small scale digital map and database compilation of soil and terrain conditions. Wageningen, The Netherlands. https://www.isric.org/documents/ document-type/isric-report-199103-soter-manual-proceduressmall-scale-digital-map-and. Accessed Sep 2021

Key RM (1992) An introduction to the crystalline basement of Africa. In: Wright EP, Burgess WG (eds) Hydrogeology of crystalline basement aquifers, 66th edn. Geological Society, London, pp 29-57

Klimke J, Franke D, Mahanjane ES, Leitchenkov G (2018) Tie points for Gondwana reconstructions from a structural interpretation of the Mozambique basin, east Africa and the Riiser-Larsen Sea, Antarctica. Solid Earth 9:25-37. https://doi.org/10.5194/ se-9-25-2018

Limaye SD (2017) Socio-hydrogeology and low-income countries: taking science to rural society. Hydrogeol J 25:1927-1930

Linton J, Budds J (2014) The hydrosocial cycle: defining and mobilizing a relational-dialectical approach to water. Geoforum 57:170 180. https://doi.org/10.1016/j.geoforum.2013.10.008

MacDonald A, Davies J, Callow RC (2008) African hydrogeology and rural water supply. In: Adelana S, MacDonald A (eds) Applied groundwater studies in Africa. CRC, Boca Raton, pp 127-148

MacDonald AM, Calow RC, Macdonald DMJ, Darling WG, Dochartaigh BEO (2009) What impact will climate change have on rural groundwater supplies in Africa? Hydrol Sci J 54(4):690-703

Meissner R, Ramasar V (2015) Governance and politics in the upper Limpopo River basin. S Afr Geoj 80(5):689-709. https://doi.org/ 10.1007/s10708-014-9589-z

Owen R, Madari N (2010) Hydrogeology of the Limpopo Basin: country studies from Mozambique, South Africa and Zimbabwe. WaterNet Working Paper 12

Peppoloni S, Di Capua G (2017) Geoethics: ethical, social and cultural implications in geosciences. Ann Geophys. https://doi.org/ 10.4401/ag-7473

Sappa G, Trotta A, Vitale S (2015) Climate change impacts on groundwater active recharge in coastal plain of Dar es Salaam (Tanzania).
In: Lollino G, Manconi A, Clague J, Shan W, Chiarle M (eds) Engineering geology for society and territory, 1st edn. Springer, Cham, pp 177-180. https://doi.org/10.1007/978-3-319-09300-0_ 34

Sappa G, Barbieri M, Vitale S (2018) Kruger national park: geological and hydrogeological assessment to save the integrity of a protected area. Int Multidisc Scient Geo Conf 18(1-2):417-424. https://doi.org/10.5593/sgem2018/1.2/S02.053

United Nations (1992) Convention on biological diversity. United Nations, Washington. https://www.cbd.int/doc/legal/cbd-en.pdf. Accessed Sep 2021

Van der Zaag P, Juizo D, Vilanculos A, Bolding A, Uiterweer NP (2010) Does the Limpopo River Basin have sufficient water for massive irrigation development in the plains of Mozambique? Phys Chem Earth 35:832-837

Van Hinsbergen DJJ, Buiter SJH, Torsvik TH, Gaina C, Webb SJ (2011) The formation and evolution of Africa from the Archaean to Present: introduction. In: Van Hinsbergen DJJ, Buiter SJH, Torsvik TH, Gaina C, Webb SJ (eds) The formation and evolution of Africa: a synopsis of $3.8 \mathrm{Ga}$ of earth history. Geological Society, London, pp 1-8. https://doi.org/10.1144/SP357.1

Vitale S, Barbieri M, Nigro A, Sappa G (2017a) Groundwater: a matter of quality and quantity in Limpopo National Park. Sens Sci 4(3):400-409. https://doi.org/10.14616/sands-2016-2-184189

Vitale S, Barbieri M, Sappa G (2017b) Integrated groundwater characterization for biodiversity protection in Limpopo National Park (Mozambique). Int Multidiscip Sci Geo Conf 17:411-419. https:// doi.org/10.5593/sgem2017/31

Wright EP (1992) The hydrogeology of crystalline basement aquifers in Africa. In: Wright EP, Burgess WG (eds) hydrogeology of crystalline basement aquifers, 66th edn. Geological Society, London, pp 1-27

Publisher's Note Springer Nature remains neutral with regard to jurisdictional claims in published maps and institutional affiliations. 